\title{
Potential of Using Design-Build in Public Procurement
}

\author{
Ing. Jakub Blaták ${ }^{1}$ \\ ${ }^{1}$ Department of Economics and Management in Civil Engineering, Faculty of Civil Engineering, Czech Technical \\ Universinty, Prague, Czech Republic. \\ Correspondence: Ing. Jakub Blaták, Department of Economics and Management in Civil Engineering, Faculty of Civil \\ Engineering, Czech Technical Universinty, Prague, Czech Republic.
}

\author{
Received: June 3, 2016 \\ Accepted: June 21, 2016 \\ Available online: July 1, 2016 \\ doi:10.11114/afa.v2i2.1708 \\ URL: http://dx.doi.org/10.11114/afa.v2i2.1708
}

\begin{abstract}
Risk is an omnipresent effect in every area of human activity. Ignoring it can cause serious problems. This article is about eliminating risk in public contracts using the design-build method as a possible solution to reduce risk. First, we need to compare the standard method of design-bid-build with its alternative, design-build. Two methods are used in this article to analyse risk - the main method is RIPRAN. The evaluated results provided by the RIPRAN method are processed by research data using a scoring method with a risk map. The analysis is going to detect the difference between the DBB and DB methods, primarily in appearance and its impact on the realization of the whole construction. The comparison identifies numerous contractual topics and risks included in both and gives deeper insight into risk management, both for the contracting party and also for public procurement. Applying risk analysis strategies and tools to the process will help decision-makers evaluate and select the most suitable delivery method consistently and defensibly. This paper gives generic risk factors related to both project types.
\end{abstract}

Keywords: design-build, RIPRAN, score method with a risk map

\section{Introduction}

Risk can be understood as the possibility of undesirable incidents occurring. These incidents are not anticipated during the building planning, construction and completion, but can happen with certain probability. The consequence of these incidents is damage. Risk is the fear of something unknown or some unknown consequences which can be linked to known phenomenon (Rozsypal, 2008). During construction, all parties face risks - the investor bears the overall financial risk of the project, the project designer bears the responsibility of the final solution and the contractor bears overall costs. Typical risks of a design-bid-build (hereafter referred to as DBB) project are different from a design-build (hereafter DB) project (Chang 2010). Traditional construction procurement approaches try to find adequate construction and building methods, which consider risk level in comparison with demands, challenges and alternative procurement routes to have the best "value for money" (Palaneeswaran 2003). For this purpose, it is critical to make a comparative overview to identify the core aspects of risk management analysis, using adequate methods (RAMP 2004, Lam 2007).

The main aim of this article is to show one of the function methods to analyse risk level and compare DBB and DB views so that the contractor can have a clear overview of the whole situation and its own needed risk level.

\section{Risk evaluation in design-build projects}

Design-Build projects can be risky for both the ordering (public procurement) and the contracting party. It is desirable to evaluate the risk by analysis (ÖZTAŞ 2004). The risk strategy is the key part of each project. The goal of the research is to confirm that there is a real reduction of risk for the public sector and quantify the risk reduction. The parts of the project where the public sector is able to reach the greatest amount of reduction and the part with no influence by the usage of the design-build scheme are also shown in the research. This can be very useful for authorities who are planning a new project, because they will know where they need to be careful so they can achieve the largest net income. All the research has been done in the area of the Czech Republic. In this case the Czech Republic is characteristic in that there is almost no usage of design-build in the public sector, even though the private sector is familiar with this scheme. The motivation is to show the advantages of design-build to public authorities (AL-RESHAID 2005).

\subsection{Risk management methods}

It is very important is to understand the main characteristic of risk management to be able to decrease the risk level. 
Risk management is the process where the managing subject makes an effort to eliminate the influence of existing and future risks and designs arrangements to remove the non-desirable influences where possible. Simultaneously, the positive influence is used - among the risk management processes belong the analysis of non-desirable influence and the risk monitoring. By using risk analysis, every risk can be identified and also the probability of expecting damages and risk responses can be considered. Risk monitoring means continual discovery to see if the risk level is invariable and the prospective arrangement does not need to be realised - as a response to the risk expectation.

Potential threats can be found and, above all, suitable reactions and arrangements can be arranged to reduce them thanks to risk analysis. Probability and possible damage must be defined. The risk identification techniques can be categorized, for example, by the documentation review, brainstorming, Delphi, the method of nominal group, interview with the expert and other methods. As the risk is identified and considered, the estimation of probability to the risk occurrence and its negative influence to the whole project is done. The evaluation can be qualitative (verbal value) or quantitative (number value). The target is to create an arrangement to decrease the probability of risk occurrence to an acceptable level. To be able to change the effectiveness of the arrangements is fundamental to follow construction rules.

Different methods can be used to create the risk analysis. The methods are divided into two groups:

- The methods of risk analysis concerning the project product

- The methods of risk analysis concerning the project management

This article is focused on the second group, as is important to give attention to the risks which arise from the basis of project management (where there is also technical risk). These methods are, for example: FRAP, the susceptibility analysis, the method of scenario planning, the decision trees or RIPRAN. The last method is described in detail in the following part.

\subsection{Research Method}

A research method called RIPRAN has been used to modify the method for evaluation of the risks (Lacko 2001). This method is designed for evaluation and reduction of the project risk in various sectors. The RIPRAN method is excellent for every phase of the ongoing project (Pavelková 2012). The basic phases of this method can be taken as the process where each phase is connected to the other phase. Found among the basic phase are: the preparation of risk analysis the identification of project hazard - the quantification of project risks - the reaction the risks - the overall risk evaluation. The manner of its composition is found between the advantages of this method, created from the international standards. The benefit is simple usage in practice which enables analysis of risk in incorrectly structured projects. This method can seem more complicated than in reality, but it is not complicated to get the recommendations and proposals to eliminate the potential risks.

The basic phases of the RIPRAN method:

- The preparation of risk analysis - the projection of the time frame creates the source of needed documentation; the output is a plan to execute the risk analysis

- The identification of project danger - the target is to find all possible threats and scenarios, the statistical data and prognoses are used; the output is a list of the threat - scenario pairs

- The quantification of project risks - the effort to evaluate the probability of listed scenarios and size of damages; the output is a chart with listed threats and scenarios and also probability, impact and risk value

- The reaction to project risks - to use the data from the prepared chart; the output is a chart complemented by columns with the proposal to arrangements, the new risk value and also the cost of the arrangements

- The overall risk evaluation - to evaluate the analysed project; the output is an overall evaluation of risk levels (Ježková 2014)

The author of the method is Doc. Ing. Branislav Lacko, CSc. The method was established for the analysis of risk in automation projects in pursuance of scientific research at VUT Brno. The praxis showed that after a few modifications, the method is applicable for analysis of various risk in many projects. RIPRANTM is a trademark registered by the office of industry ownership in Prague (Ježková 2014).

\subsection{Research process}

For our research, part of the RIPRAN method was used for evaluation of the typical risks of a design-bid-build (DBB) project and separately for a design-build (DB) project.

The research has been done in four steps:

- Identification of the risks

- Inspection of the risk matrix 
- Evaluation of the risks

- Appraisal of the results

\subsubsection{Identification of the risks}

In this step, an economic survey was carried out to find as many risks for construction projects as possible. The survey was done by questioning 12 construction managers (PMBOK Guide 2004). Each respondent had to write down a list of risks which he or she thinks is relevant to the comparison of DBB and DB. The final list was discussed with the respondent to get the right projection of what he or she meant by each risk. Finally, all the lists were matched and the duplicated data was deleted (Chang 2010). Because the final list has almost 150 records, it was necessary to determine groups and sub-groups of risks. Each of the risks was described as part of a pair: threat and scenario. For example, the threat could be an actual danger (e.g. a lightning strike) and the scenario would be the result which is caused by the threat (e.g. a fire). In this phase, 149 pairs of risks were identified, which were split into 9 chapters.

Table 1. Risk chapters

\begin{tabular}{cc}
\hline Risk chapter number & Risk chapter name \\
\hline 1 & Security area \\
2 & Ecological area \\
3 & Economical area \\
4 & Management and decision making \\
5 & Political \\
6 & Law and regulatory area \\
7 & Social and personal area \\
8 & Technological area \\
9 & Other \\
\hline
\end{tabular}

Discription: 9 identified areas of risk

It was necessary to look at the risks from the public authority's point of view, and also in the same manner, to make an evaluation of the risks (Edwards 1995). The main criteria for the evaluation was the level of the influence on public procurement.

Table 2. Example of the risk matrix

\begin{tabular}{|c|c|c|c|}
\hline Area & Type of risk & Threat & Scenario \\
\hline Planning quality & R110 & $\begin{array}{l}\text { Bad estimate of area requirements } \\
\text { for the building site }\end{array}$ & Not possible to continue \\
\hline Planning quality & R111 & $\begin{array}{l}\text { Contradiction between bills of } \\
\text { quantities and planning }\end{array}$ & Increase of cost \\
\hline Planning quality & $\mathrm{R} 112$ & $\begin{array}{l}\text { Contradiction between bills of } \\
\text { quantities and planning }\end{array}$ & $\begin{array}{l}\text { Prolongation of time } \\
\text { schedule due to solution } \\
\text { finding }\end{array}$ \\
\hline Planning quality & R113 & $\begin{array}{l}\text { Contradiction between parts of } \\
\text { planning }\end{array}$ & Increase of cost \\
\hline Planning quality & $\mathrm{R} 114$ & $\begin{array}{l}\text { Contradiction between parts of } \\
\text { planning }\end{array}$ & $\begin{array}{l}\text { Prolongation of time } \\
\text { schedule due to solution } \\
\text { finding }\end{array}$ \\
\hline Planning quality & R115 & $\begin{array}{l}\text { Contradiction between parts of } \\
\text { planning }\end{array}$ & $\begin{array}{l}\text { Difficult setup of } \\
\text { responsibility }\end{array}$ \\
\hline
\end{tabular}

\section{Discription: Threat and scenario for each risk type}

\subsubsection{Inspection of the risk matrix}

In this step, the final risk matrix was checked with the respondents from the first step. This ensured that the basis for the future research respected the reality of the market. Of course, the meaning of each risk and the correctness of the threat and scenario pair was also discussed (Flangan 1993). The goal of this step was to finalize the list of risks and clarify the meaning of each risk. 


\subsubsection{Evaluation of the risks}

Concrete threats and scenarios were judged by their probability and influence on the project. This was done for DB and DBB separately. The chart $n$. 3 shows the level of risk probability and the possibility of overall impact by using three probability values - low, middle and high. In DB projects, some risks are transferred to the contracting side from the public procurement side, so that the probability or influence could be lowered, as can be seen from the example in Table 3.

Table 3. Example of probability and impact quantification

\begin{tabular}{|c|c|c|c|c|c|}
\hline Threat & Scenario & $\begin{array}{l}\text { DBB Probability of } \\
\text { occurence }\end{array}$ & $\begin{array}{l}\text { DBB Project } \\
\text { impact effect }\end{array}$ & $\begin{array}{l}\text { DB Probability of } \\
\text { occurence }\end{array}$ & $\begin{array}{l}\text { DB Project impact } \\
\text { effect }\end{array}$ \\
\hline $\begin{array}{l}\text { Contradiction } \\
\text { between bills of } \\
\text { quantities and } \\
\text { planning }\end{array}$ & Increase of cost & $\begin{array}{c}\text { High } \\
\text { probability }\end{array}$ & $\begin{array}{l}\text { Middle } \\
\text { unfavourable } \\
\text { impact }\end{array}$ & $\begin{array}{c}\text { Low } \\
\text { probability }\end{array}$ & $\begin{array}{c}\text { Middle } \\
\text { unfavourable } \\
\text { impact }\end{array}$ \\
\hline $\begin{array}{l}\text { Additional } \\
\text { investments not } \\
\text { predicted during } \\
\text { planning }\end{array}$ & Increase of cost & $\begin{array}{r}\text { Middle } \\
\text { probability }\end{array}$ & $\begin{array}{c}\text { Middle } \\
\text { unfavourable } \\
\text { impact }\end{array}$ & $\begin{array}{r}\text { Middle } \\
\text { probability }\end{array}$ & $\begin{array}{l}\text { Low } \\
\text { unfavourable } \\
\text { impact }\end{array}$ \\
\hline $\begin{array}{l}\text { Non-complete } \\
\text { documentation }\end{array}$ & $\begin{array}{l}\text { Prolongation of } \\
\text { construction }\end{array}$ & $\begin{array}{r}\text { Middle } \\
\text { probability }\end{array}$ & $\begin{array}{l}\text { Middle } \\
\text { unfavourable } \\
\text { impact }\end{array}$ & $\begin{array}{c}\text { Low } \\
\text { probability }\end{array}$ & $\begin{array}{c}\text { Middle } \\
\text { unfavourable } \\
\text { impact }\end{array}$ \\
\hline $\begin{array}{c}\text { Changes } \\
\text { caused by the } \\
\text { selection of } \\
\text { technical equipment }\end{array}$ & Increase of cost & $\begin{array}{r}\text { Middle } \\
\text { probability }\end{array}$ & $\begin{array}{c}\text { High } \\
\text { unfavourable } \\
\text { impact }\end{array}$ & $\begin{array}{c}\text { Low } \\
\text { probability }\end{array}$ & $\begin{array}{c}\text { High } \\
\text { unfavourable } \\
\text { impact }\end{array}$ \\
\hline $\begin{array}{c}\text { Bad } \\
\text { information transfer } \\
\text { between designer } \\
\text { and builder }\end{array}$ & $\begin{array}{l}\text { Prolongation of } \\
\text { construction }\end{array}$ & $\begin{array}{r}\text { Middle } \\
\text { probability }\end{array}$ & $\begin{array}{c}\text { High } \\
\text { unfavourable } \\
\text { impact }\end{array}$ & $\begin{array}{c}\text { Low } \\
\text { probability }\end{array}$ & $\begin{array}{c}\text { Low } \\
\text { unfavourable } \\
\text { impact }\end{array}$ \\
\hline
\end{tabular}

Discription: DBB and DB comparison

After the identification of risks for every threat and scenario and after adding the possible impact on the project, the risk level was quantified (Alali 2009). The risk level was defined separately for each type of project in the construction Design-Bid-Build (DBB) and Design-Build (DB). The risk level was defined by the mixture of the probability and the impact on the project. The method is shown in Table 4.

Table 4. Risk Evaluation

\begin{tabular}{cccc}
\hline & $\begin{array}{c}\text { High unfavourable } \\
\text { impact }\end{array}$ & $\begin{array}{c}\text { Middle unfavourable } \\
\text { impact }\end{array}$ & $\begin{array}{c}\text { Low unfavourable } \\
\text { impact }\end{array}$ \\
\hline High probability & High risk level & High risk level & Middle risk level \\
Middle probability & High risk level & Middle risk level & Low risk level \\
Low probability & Middle risk level & Low risk level & Low risk level \\
\hline
\end{tabular}

\section{Discription: Risk level}

Finally, all types of risks were considered and judged by numbers $(1,2,3)$ as well as by verbal evaluation (high, middle, low risk level) of the overall level of probability connected with the possibility of total impact on the project (Wang 2004). For DBB projects, the final average risk level for the public sector is 1,8 and for DB projects the final average risk level is 1,5. It shows that by using design-build, the risk is decreased by $17 \%$. In Table 5 the evaluation of the risks is shown. 
Table 5. Example of Risk Level Quantification

\begin{tabular}{|c|c|c|c|c|c|c|c|}
\hline Threat & Scenario & $\begin{array}{c}\text { DBB } \\
\text { Probability of } \\
\text { occurence }\end{array}$ & $\begin{array}{l}\text { DBB Project } \\
\text { impact effect }\end{array}$ & DBB Risk & $\begin{array}{l}\text { DB } \\
\text { Probability of } \\
\text { occurence }\end{array}$ & $\begin{array}{l}\text { DB Project } \\
\text { impact effect }\end{array}$ & DB Risk \\
\hline \multicolumn{8}{|l|}{ Contradic } \\
\hline tion between & & & Middle & & & Middle & \\
\hline & Increase & High & & High risk & Low & & Low risk \\
\hline bills of & & & unfavourable & & & unfavourable & \\
\hline & of cost & probability & & level -3 & probability & & level - 1 \\
\hline quantities and & & & impact & & & impact & \\
\hline \multicolumn{8}{|l|}{ planning } \\
\hline \multicolumn{8}{|l|}{ Addition } \\
\hline al investments & & & Middle & & & Low & \\
\hline & Increase & Middle & & Middle & Middle & & Low risk \\
\hline not predicted & & & unfavourable & & & unfavourable & \\
\hline during & of cost & probability & impact & risk level - 2 & probability & impact & level - 1 \\
\hline \multicolumn{8}{|l|}{ planning } \\
\hline \multicolumn{8}{|l|}{ Incomple } \\
\hline & Prologist & & Middle & & & Middle & \\
\hline te & & Middle & & Middle & Low & & Low risk \\
\hline & of & & unfavourable & & & unfavourable & \\
\hline documentatio & & probability & & risk level - 2 & probability & & level - 1 \\
\hline \multicolumn{8}{|l|}{$\mathrm{n}$} \\
\hline \multicolumn{8}{|l|}{ Changes } \\
\hline caused by the & & & High & & & High & \\
\hline & Increase & Middle & & High risk & Low & & Middle \\
\hline selection of & & & unfavourable & & & unfavourable & \\
\hline & of cost & probability & & level - 3 & probability & & risk level - 1 \\
\hline technical & & & impact & & & impact & \\
\hline equipment & & & & & & & \\
\hline
\end{tabular}

Description: DBB and DB risk level comparison

\subsubsection{Appraisal of the results}

By the comparison of each pair, the parts of the project where the usage of design-build decreased the risk were identified (Tah 2001). There are 43 threats which are affected by using design-build. What is really interesting is the amount of decreased risks for each chapter, which can be seen in Table 6.

Table 6. Amout of risk decrease by chapters

\begin{tabular}{cc}
\hline Area & Amount of risk \\
\hline Security area & 0 \\
Ecological area & 2 \\
Economical area & 5 \\
Management and decision making & 14 \\
\hline
\end{tabular}




\begin{tabular}{cc}
\hline Political & 0 \\
Law and regulatory area & 7 \\
Social and personal area & 0 \\
Technological area & 15 \\
Other & 0 \\
\hline
\end{tabular}

\section{Description: Amount of risk in each area}

It can be seen from the table that the biggest risk decrease is made in the area of "management" and "decision making and in the technological area". On the other hand, this means that it is imperative for project managers to precisely define these areas in the contract and to focus on risk transfer in those areas (Kamara 2002). In the next table you can see the average risk for each area of design-bid-build (standard) project.

Table 7. Average risk on design-bid-build projects by chapters

\begin{tabular}{cc}
\hline Area & Average risk \\
\hline Security area & 1,25 \\
Ecological area & 1,75 \\
Economical area & 1,8 \\
Management and decision making & 2,36 \\
Political & 1 \\
Law and regulatory area & 2 \\
Social and personal area & 1,29 \\
Technological area & 2,13 \\
Other & 2 \\
\hline
\end{tabular}

Description: Average risk in each area

By a comparison of Table 6 and Table 7, it can be seen that by the usage of design-build, it is possible to decrease most high-risk areas, because the areas "Management and Decision Making" and "Technological Area" have the biggest average risk and the highest amount of decreased risks at the same time.

This directly shows how effective the design-build scheme can be for the public sector (Forbes 2008). By transferring the risk responsibility to the contractor, they can extend their field of operation and responsibility. The contractor is also responsible for the planning and the building construction during the project realization. Design-build decreases the risks which are the most important for the contractor, and should help the public sector to be more effective.

\subsection{The scoring method with a risk map}

To discover the effectiveness of the RIPRAN method, it is necessary to process data by another method to have comparable results. The comparative method is a scoreing method with a risk map. This method is composed of three parts - the identification of risk, the evaluation of risk and the proposals for risk elimination.

a) Risk identification

The first step is to identify potential risk. The data is taken from the same research as the RIPRAN method and is focused on the level of influence on public contracts.

b) Risk evaluation

The second part evaluates risk. Each potential risk is rated on a scale of 1-10, according to the probability of the risk's occurrence and the possible consequences ( 1 being the lowest and 10 being the highest). 
Table 8. Probability and impact

\begin{tabular}{ccccc}
\hline Risk & $\begin{array}{c}\text { DBB } \\
\text { Probability }\end{array}$ & DBB Impact & $\begin{array}{c}\text { DB } \\
\text { Probability }\end{array}$ & DB Impact \\
\hline $\begin{array}{c}\text { Contradiction between measurement } \\
\text { statements and project documentation } \\
\begin{array}{c}\text { Produced investments, unexpected in } \\
\text { the tender offers }\end{array}\end{array}$ & 8 & 6 & 2 & 5 \\
$\begin{array}{c}\text { Insufficient documentation } \\
\text { Changes caused by choice of } \\
\text { technology / devices }\end{array}$ & 6 & 4 & 5 & 2 \\
$\begin{array}{c}\text { Informational noise between the } \\
\text { project designer and the contractor }\end{array}$ & 5 & 10 & 2 & 6 \\
\hline
\end{tabular}

Discription: DBB and DB probability and impact comparison

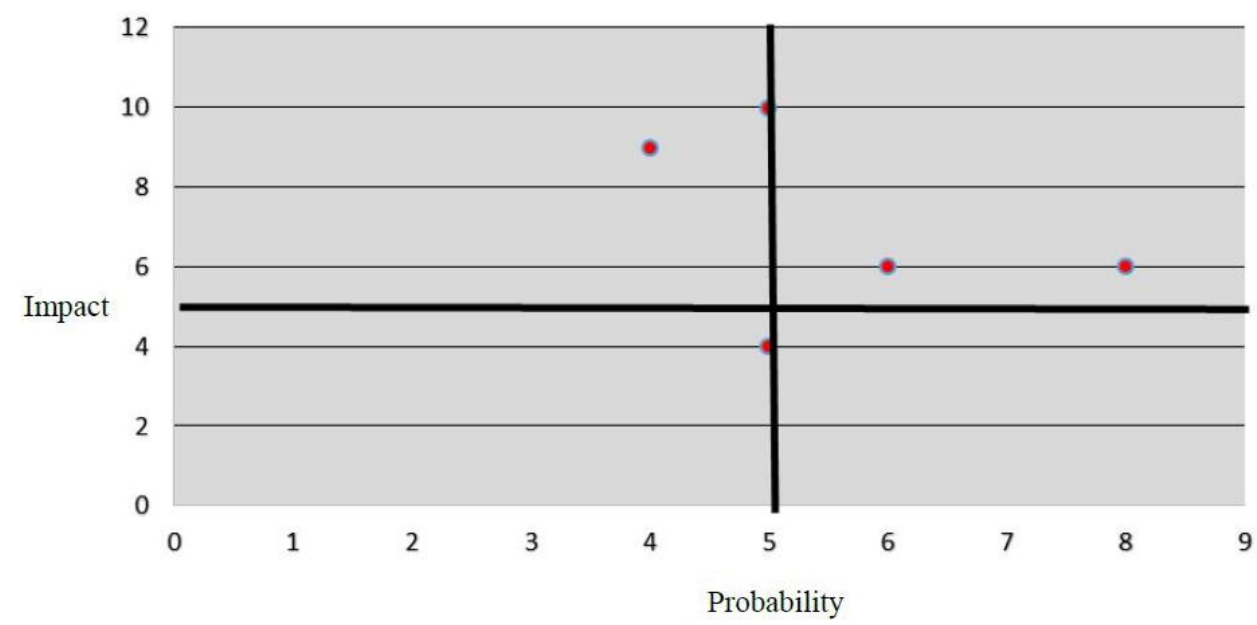

Figure 1. Risk map of DBB

Description: Probability and impact of potential risk in DB projects.

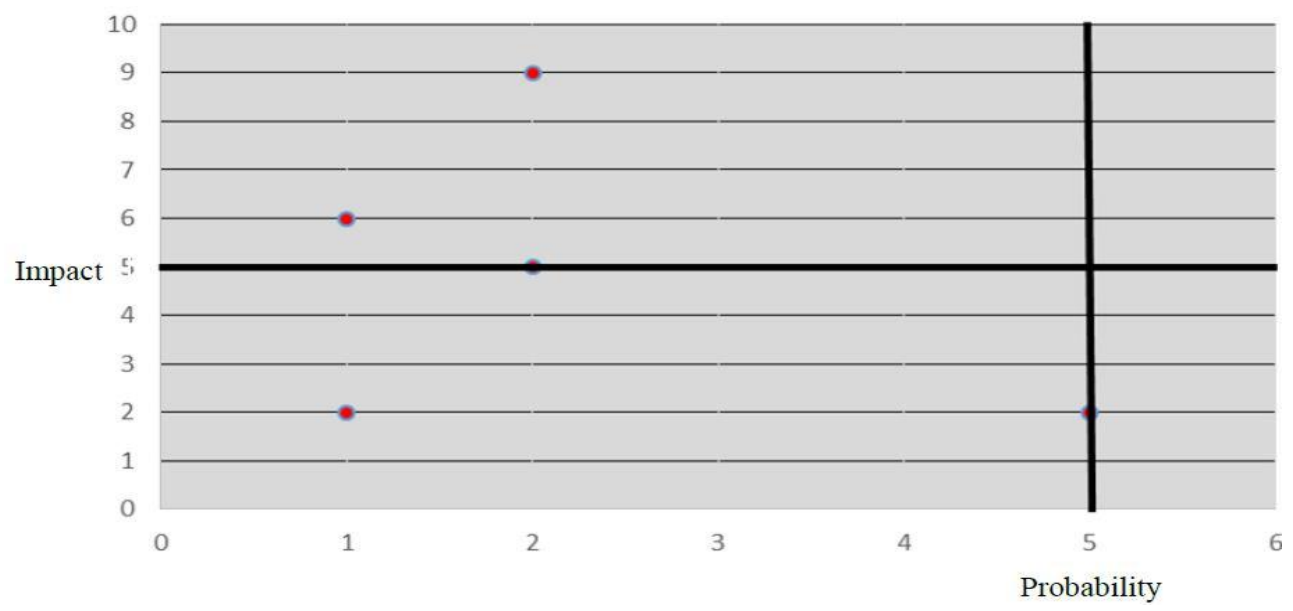

Figure 2. Risk map of DB

Description: Probability and impact of potential risk in DB projects.

The risk level can be deduced from the risk map, which are critical for public contracts and cannot be neglected. The DBB risk map puts forward the fact that the probability of serious risk formation is high and the importance of risk elimination is seen as the only possible solution. Design-build eliminates critical risks (as shown in the chart ... in the I. quadrant) and decreases the probability of serious risk formation (II. quadrant). Indisputably, design-build is advantageous for the realization of public contracts because this method decreases risk in all areas which are riskier in 
the standard method (DBB).

c) Proposal to decrease risk

The final phase of the scoring method includes a phase to decrease potential risk. Risk and its impacts are analysed and matched to the most suitable solution.

Table 9. Risk Arrangement

\begin{tabular}{|c|c|}
\hline Risk & Solution \\
\hline $\begin{array}{l}\text { Contradiction between measurement } \\
\text { statement and project documentation }\end{array}$ & Time saving \\
\hline $\begin{array}{l}\text { Produced investments, unexpected in } \\
\text { the tender offers }\end{array}$ & Analysis of unexpected risks \\
\hline Insufficient documentation & Experienced employees \\
\hline $\begin{array}{l}\text { Changes caused by choice of } \\
\text { technology / devices }\end{array}$ & Analysis of accessible technologies \\
\hline $\begin{array}{l}\text { Informational noise between the project } \\
\text { designer and the contractor }\end{array}$ & $\begin{array}{l}\text { Improvement of communication } \\
\text { between the project designer and the } \\
\text { contractor }\end{array}$ \\
\hline
\end{tabular}

Description: Solution for each risk

\section{Results}

Risk analysis is key for each building project. It can discover potential risks and their impact on the realization of the project and can also allocate each risk to the concrete project's subject. So, the formation of the solution is more effective and this way also prevents risk entirely.

By using the RIPRAN method, the standard DBB method was compared with its alternative method, DB. It was proved that the DB method is more advantageous because it eliminates critical risks, which the standard DBB method does not do. Moreover, it transfers some risk and responsibility to the contractor and the contractor becomes responsible for protection against risk formation or reducing incurred risk.

To evaluate the effectiveness of the RIPRAN method, the scoring method with a risk map was also used. The characteristics of this method are similar to the RIPRAN method, which is why it was chosen for verification. The risk map represents the probability and seriousness of each risk and the results were identical to the RIPRAN method.

The RIPRAN method and the scoring method are both suitable for risk analysis. Both methods can evaluate risk based on its probability and impact. The RIPRAN method, even if it is complicated and time consuming, provides better risk analysis than the scoring method. RIPRAN can be used in each phase of the project, even if the project is not well structured. RIPRAN is the main research method because of its benefits, which include: exact results, clear arrangements and usefulness in any phase of the project.

\section{References}

Alali, B., \& Pinto, A. (2009). Project, systems and risk management processes interactions. Management of Engineering \& Technology. http://dx.doi.org/10.1109/PICMET.2009.5261999.

Al-Reshaid, K., \& Kartam, N. (2005). Design-build pre-qualification and tendering approach for public projects. International Journal of Project Management, 23(4), 309-320. http://dx.doi.org/10.1016/j.ijproman.2004.11.004.

Chang, A., Shen, F., \& Ibbs, W. (2010). Design and construction coordination problems and planning for design-build project new users. Canadian Journal of Civil Engineering. http://dx.doi.org/10.1139/L10-090.

Edwards, L. (1995). Practical risk management in the construction industry. London, Thomas Telford. ISBN 0727733907.

Flangan, R. (1993). Risk management and construction. Oxfor, Blackwell Science. ISBN: 0-632-02816-5.

Forbes, D., Smith, S., \& Horner, M. (2008). Tools for selecting appropriate risk management techniques in the built environment. Construction Management and Economics. 26, 1241-1250. http://dx.doi.org/10.1080/01446190802468487.

Ježková Z., Krejčí H., \& Lacko B. (2014). Projektové rízení - Jak zvládnout projekty. Kuřim: Akademické centrum studentských aktivit. (ISBN 978-80-905297-1-7). 
Kamara, J., Augenbroe, G., Anumba, C., \& Carrillo, M. (2002). Knowledge management in the architecture, engineering and construction industry. Construction Innovation: Information, Process, Management, 2(1), 53-67. http://dx.doi.org/10.1108/14714170210814685.

Lacko, B. (2001). Aplikace metody RIPRAN v softwarovém inženýrství. In: Sborník celostátní konference TVORBA SOFTWARU 2001, VŠB Ostrava, Str.97 - 103. (ISBN 80-85988-59-3).

Lam, K., et al. (2007). Modelling Risk Allocation Decision in Construction Contracts. International Journal of Project Management, 25, 485-493. http://dx.doi.org/10.1016/j.ijproman.2006.11.005.

Öztas A., \& Ökmen O. (2004). Risk analysis in fixed-price design-build construction projects. Building and Environment, 39(2), 229-237. http://dx.doi.org/10.1016/j.buildenv.2003.08.018. ISSN 03601323.

Palaneeswaran, E., Kumaraswamy, M., \& Ng, T. (2003). Targeting optimum value in public sector projects through "best value"-focused contractor selection. Engineering, Construction and Architectural Management. http://dx.doi.org/10.1108/0969998310509390.

Pavelková, M., \& Korytárová, J. (2012). Analýza rizik a nejistot projektu Moravian Science Centre Brno. Stavební obzor, 21, č. 10, s. 312-320. ISSN 1805-2576.

PMBOK Guide (2013). A Guide to Project Management Body of Knowledge (Fifth Ed.). Project Management, Institute, Pennsylvania, 310 - 320, ISBN 9781935589679.

RAMP. Risk Analysis and Management for Projects. (2004). ICE-Institution of Civil Engineers, Faculty of Actuaries, and Institute of Actuaries, London.

Rozsypal, A. (2008). Inženýrské stavby: ř́zení rizik. 1st edition. Bratislava: JAGA. ISBN 978-80-8076-066-3.

Tah, J., \& Carr, V. (2001). Knowledge-Based Approach to Construction Project Risk Management. Journal of Computing in Civil Engineering, 15(3), 170-177. http://dx.doi.org/10.1061/(ASCE)0887-3801(2001)15:3(170).

Wang, S., Dulaimi, M., \& Aguria, Y. (2004). Risk management framework for construction projects in developing countries. Construction Management and Economics, 22(3), 237-252. http://dx.doi.org/10.1080/0144619032000124689.

\section{$(\mathrm{cc}) \mathrm{BY}$}

This work is licensed under a Creative Commons Attribution 3.0 License. 